\section{PENGUATAN KAPASITAS MASYARAKAT MELALUI INOVASI FORMULASI KEBIJAKAN PERENCANAAN PEMBANGUNAN PARTISIPATIF DI KECAMATAN WANASALAM KABUPATEN LEBAK}

\author{
Ahmad Sururil dan Rahmi \\ Mulyasih $^{2}$
}

1)Administrasi Negara, Universitas Serang Raya

2)॥mu Komunikasi, Universitas Serang Raya

$\begin{array}{ll}\text { Article history } & \\ \text { Received } & : \text { 22-09-2017 } \\ \text { Revised } & : 08-11-2017 \\ \text { Accepted } & \text { : 09-10-2017 }\end{array}$

\section{*Corresponding author}

Ahmad Sururi

Email : ahmadbroer@gmail.com

\begin{abstract}
Abstraksi
Tujuan dari kegiatan pengabdian masyarakat ini adalah melakukan pendampingan bersama-sama masyarakat dalam menyusun formulasi kebijakan perencanaan pembangunan yang inovatif dan partisipatif secara berkelanjutan dalam menghasilkan dokumen perencanaan sebagai rujukan dan rekomendasi RPJMD dan RKPD. Faktor dampak yang diharapkan adalah mendorong penguatan kapasitas masyarakat desa baik secara individu maupun kelompok melalui partisipasi aktif masyarakat dengan memanfaatkan potensi dan sumber daya lokal yang dimiliki sehingga dapat melahirkan kader-kader perencana pembangunan desa dan bertransformasi menjadi aktor-aktor kebijakan pembangunan sebagai subjek formulasi kebijakan. Penguatan Kapasitas Masyarakat berbasis inovasi formulasi kebijakan dilaksanakan melalui prinsip-prinsip: (i)masyarakat adalah aktor utama perencana pembangunan dan diposisikan sebagai penentu/pengambil kebijakan; (ii)mengutamakan nilai-nilai kearifan lokal yang tercakup dalam modal sosial sesuai dengan karakteristik sosial, budaya dan potensi geografis; (iii)pemerintah desa adalah fasilitator yang memfasilitasi masyarakat desa dalam penyusunan inovasi formulasi kebijakan perencanaan pembangunan. Sedangkan Metode yang digunakan adalah Participatory Rapid Appraisal (PRA) atau penilaian desa secara partisipatif. Hasil kegiatan pengabdian masyarakat berjalan sesuai dengan rencana yang telah ditetapkan. Tahapan-tahapan kegiatan pendampingan berjalan dengan cukup baik mulai dari sosialisasi, observasi dan survey, identifikasi, analisis pemecahan masalah serta penyusunan dokumen perencanaan pembangunan untuk diserahterimakan kepada pemerintah desa sebagai bahan rekomendasi/rujukan penyusunan RPJMD dan RKPD.
\end{abstract}

Keywords: Penguatan Kapasitas Masyarakat, Inovasi formulasi kebijakan, perencanaan pembangunan partisipatif

\begin{abstract}
The purpose of this community service activity is to co-ordinate with the community in developing innovative and participatory development planning policy formulation in a sustainable manner to produce the document as reference and recommendation of RPJMD and RKPD. The expected impact factor is to encourage the strengthening of the capacity of villagers both individually and in groups through the active participation of the community by utilizing local potentials and resources so as to generate village development planning cadres and transforming them into development policy actors as the subject of policy formulation. Strengthening Community Capacity-based innovation policy formulation is implemented through the following principles: (i) the community is the main actor of the development planner and is positioned as the decision maker / policy maker; (ii) prioritizing the values of local wisdom included in social capital in accordance with social, cultural and geographic characteristics; (iii) village governments are facilitators who facilitate village communities in developing innovative development planning policy formulations. The method used is Participatory Rapid Appraisal (PRA) or participatory village appraisal. The results of community service activities run in accordance with the predetermined plans. The stages of advisory activities are running well from socialization, observation and survey, identification, problem solving analysis and preparation of development planning documents to be handed over to village government as recommendation / reference materials for the preparation of RPJMD and RKPD.
\end{abstract}

Keywords: Strengthening Community Capacity, Innovation of policy formulation, participatory development planning 


\section{PENDAHULUAN \\ Latar Belakang Masalah}

Pembangunan berbasis masyarakat yang berbasis pada potensi dan sumberdaya lokal, modal sosial, budaya lokal dan kearifan lokal menjadi prasyarat penting keberhasilan program pembangunan di suatu daerah. Untuk itu kemampuan pemerintah baik dalam skala lokal maupun nasional dalam mengakomodir aspirasi dan partisipasi masyarakat dalam proses pembangunan menjadi sebuah upaya yang efektif dalam rangka menciptakan kemitraan yang strategis antara pemerintah dan masyarakat serta mendorong partisipasi masyarakat secara komprehensif. Dengan demikian perencanaan pembangunan akan direalisasikan sesuai dengan kebutuhan dan aspirasi masyarakat serta diharapkan mampu menjawab tantangan dan permasalahan yang dihadapi oleh masyarakat tersebut. Dalam hal ini pelibatan masyarakat dalam perencanaan pembangunan dimulai dari proses identifikasi kebutuhan, pemetaan permasalahan sampai dengan tahap pelaksanaan dan pengawasan kegiatan. Hal tersebut sejalan dengan perubahan paradigma pembangunan yang selama ini tersentralisasi dengan menempatkan suatu daerah atau wilayah sebagai objek pembangunan menjadi desentralisasi atau menempatkan daerah atau wilayah sebagai subjek pembangunan sehingga aktor utama pembangunan di suatu daerah adalah seluruh masyarakat dengan dukungan berbagai komponen di tingkat lokal dan segenap potensi sumber daya yang dimiliki oleh daerah tersebut.

Penguatan kapasitas adalah penguatan kemampuan yang dimiliki oleh setiap individu (dalam masyarakat), kelembagaan, maupun sistem atau jejaring antar individu dan kelompok/organisasi sosial serta pihak lain diluar sistem masyarakatnya sampai di aras global (Mardikanto, 2013:69). Pentingnya penguatan kapasitas masyarakat desa terkait inovasi kebijakan perencanaan pembangunan berkelanjutan dalam pengelolaan pembangunan desa menjadi upaya dan strategi dalam merekonstruksi proses perubahan sosial budaya, ekonomi dan politik menuju kesejahteraan masyarakat desa yang didesain secara bottom up atau bersifat akar rumput dan dilakukan secara swadaya dalam memberikan pengayaan kepada masyarakat untuk berkembang dan menjadi komunitas pembelajar (learning communities) yang terus tumbuh dalam sebuah proses yang terus menerus (on going process).

Dalam mewujudkan partisipasi masyarakat yang ideal maka dibutuhkan kolaborasi yang efektif antara pemerintah dengan masyarakat. Dalam hal ini masyarakat diberikan space kebebasan dalam mengambil keputusan yang bersifat strategis terkait dengan pengelolaan sumber daya potensi lokal yang dimiliki dan diberikan prioritas untuk berkembang sesuai dengan modal sosial yang dimiliki. Modal sosial dimaknai sebagai nilai atau norma bersama yang diyakini mampu menjaga kestabilan sosial melalui mekanisme tertentu yang bersifat humanis meskipun kadang-kadang irasional (Ari Dwipayana dan Sutoro Eko, 2003:104) yang mampu menjadi basis semangat partisipasi masyarakat dalam proses pembangunan. Modal sosial sebagai setiap hubungan yang terjadi dan diikat oleh suatu kelompok (trust), kesalingpengertian (mutual-under standing) dan nilai-nilai bersama (share value) yang mengikat anggota kelompok untuk membuat kemungkinan aksi bersama dapat dilakukan secara efisien dan efektif (Cohen dan Prusak L, 2001 dalam Theresia, 2014:36)

Pemerintahan desa sebagai bagian dari sistem sosial memiliki peran yang sangat penting dalam pengelolaan modal sosial yang dimiliki oleh masyarakat sehingga modal sosial masyarakat desa yang berupa norma, tradisi, kepercayaan, jaringan sosial, toleransi, gotong rotong dan nilai-nilai lokal lainnya dapat menjadi pilar pembangunan yang langsung diprakarsai oleh masyarakat desa selaku aktor pemberdayaan dan partisipasi dalam proses perencanaan pembangunan. Faktor penting modal sosial dalam proses perencanaan pembangunan tersebut termanifestasikan dalam berbagai norma, kerjasama dan jaringan antar individu dalam masyarakat desa yang bersifat volunteer sehingga modal sosial juga dapat dipahami sebagai serangkaian norma, jaringan dan organisasi dimana masyarakat mendapat akses pada kekuasaan dan kebijakan dilakukan (Putnam, 1992 dalam Mardikanto, 2013).

Dalam konteks penguatan kapasitas masyarakat diperlukan formulasi kebijakan sebagai inti dari proses pembuatan kebijakan publik yang mensyaratkan penguasaan ilmu pengetahuan yang relevan dan teruji untuk menghasilkan alternatif-alternatif solusi yang mengarah kepada pemecahan masalah publik dalam agenda kebijakan tersebut (Deddy Mulyadi, 2015:10) sehingga grand design perencanaan pembangunan bersifat inovatif dan tercipta dalam sebuah proses yang dapat menjawab dinamika dan kebutuhan masyarakat yang lebih akomodatif dan didasarkan pada kondisi objektif masyarakat bahwa yang paling tahu dan memahami apa dan bagaimana kebutuhan pembangunan adalah masyarakat itu sendiri. Disisi lain formulasi kebijakan perencanaan pembangunan yang diinisiasi secara 
langsung oleh masyarakat adalah sebuah inovasi formulasi kebijakan dimana masyarakat sebagai aktor utama pembangunan memiliki bargaining position dalam bentuk kemandirian dan independensi.

Selanjutnya dalam Undang-undang Nomor 6 tahun 2014 tentang Desa disebutkan bahwa salah satu kewenangan pemerintah desa adalah menyusun perencanaan pembangunan desa sesuai dengan perencanaan pembangunan Kabupaten/Kota yang dilaksanakan melalui mekanisme Musyawarah Perencanaan Pembangunan (Musrenbang) Desa. Disebutkan bahwa dalam Musrenbang Desa ditetapkan prioritas, program, kegiatan, dan kebutuhan pembangunan desa yang didanai oleh Anggaran Pendapatan dan Belanja Desa, swadaya masyarakat Desa, dan/atau Anggaran Pendapatan dan Belanja Daerah Kabupaten/Kota. Meskipun demikian pelaksanaan Musrenbang Desa tidak serta merta menjadi representasi dari sebuah proses perencanaan pembangunan desa yang sesungguhnya. Sekalipun struktur dan perencanaan pembangunan dilaksanakan melalui mekanisme Musrenbang akan tetapi kultur dan tradisi paternalistik yang memprosisikan kepala desa sebagai orang yang berpengaruh begitu melekat dan tidak dapat dilepaskan begitu saja sehingga membuat daya inovasi masyarakat dalam Musrenbang Desa menjadi terbatas.

Disisi lain Musrenbang Desa sebagai forum musyawarah antara masyarakat dan aparat pemerintahan hanya dilaksanakan secara seremonial dan sekedar menggugurkan kewajiban bagi aparat pemerintah desa dalam penyusunan Rencana Pembangunan Jangka Menengah Desa (RPJMD) dan Rencana Kerja Pemerintahan Desa (RKPD) sehingga kehadiran masyarakat diposisikan secara pasif dan hanya mendengarkan programprogram kerja pembangunan desa yang telah digagas oleh aparat pemerintahan desa. Dalam hal ini RPJMD dan RKPD sebagai dokumen perencanaan masih disusun tanpa melibatkan peran aktif dari masyarakat untuk mengemukakan permasalahan-permasalahan yang selama ini menjadi hambatan-hambatan dan menjadi kebutuhan masyarakat. Hal tersebut ditambah dengan problem partisipasi masyarakat yang masih lemah dan dibatasi hanya sebagai pelaksana pembangunan yang sudah direncanakan oleh pemerintah. Sebagaimana dikemukakan Lukman Sutrisno (1995:207) bahwa partisipasi masyarakat adalah kemauan rakyat untuk mendukung secara mutlak program-program pemerintah yang dirancang dan ditentukan tujuannya oleh pemerintah. Partisipasi dan aktualisasi masyarakat yang minim dalam formulasi kebijakan perencanaan pembangunan tersebut menyebabkan lemahnya pengawasan masyarakat terhadap proses implementasi dan evaluasi kebijakan perencanaan pembangunan tersebut. Selain itu formulasi kebijakan perencanaan pembangunan desa masih dirumuskan berdasarkan kepentingan jangka pendek dan tidak disusun berdasarkan identifikasi dan prioritas kebutuhan masyarakat $\mathrm{Hal}$ ini disebabkan karena agenda perencanaan pembangunan desa disusun secara parsial dan bukan berdasarkan aspirasi masyarakat desa melalui forum-forum musyawarah warga desa di tiap-tiap Rukun Tetangga (RT) dan Rukun Warga (RW) sehingga urgensi perencanaan pembangunan desa hanya melihat kepentingan aparat pemerintahan desa secara umum dan tidak melihat kepentingan masyarakat desa di tiap-tiap dusun dan kampung.

Tujuan dari kegiatan pengabdian masyarakat ini adalah melakukan pendampingan bersama-sama masyarakat dalam menyusun formulasi kebijakan perencanaan pembangunan yang inovatif dan partisipatif secara berkelanjutan dalam menghasilkan dokumen sebagai rujukan dan rekomendasi RPJMD dan RKPD. Faktor dampak yang diharapkan adalah mendorong penguatan kapasitas masyarakat desa baik secara individu maupun kelompok melalui partisipasi aktif masyarakat dengan memanfaatkan potensi dan sumber daya lokal yang dimiliki sehingga dapat melahirkan kader-kader perencana pembangunan desa dan bertransformasi menjadi aktor-aktor kebijakan pembangunan sebagai subjek formulasi kebijakan.

Kegiatan pengabdian masyarakat ini bekerjasama dengan masyarakat di 2 (dua) desa di Kecamatan Wanasalam Kabupaten Lebak yaitu Desa Parungsari dan Desa Cisarap. Mitra pertama kegiatan pengabdian masyarakat ini adalah Desa Cisarap yang berbatasan dengan :

a. Sebelah utara berbatasan dengan Desa Parungpanjang dan Desa Parungsari Kecamatan Wanasalam

b. Sebelah Selatan berbatasan dengan Desa Wanasalam dan Desa Cipedang.

c. Sebelah Barat berbatasan dengan Kecamatan Cikeusik Kabupaten Pandeglang

d. Sebelah Timur berbatasan dengan Desa Bejod Kecamatan Malingping.

Jarak tempuh Desa Cisarap ke pusat pemerintahan kecamatan yaitu $7 \mathrm{~km}$, ke pusat kabupaten lebak yaitu $70 \mathrm{~km}$ dan jarak ke ibukota propinsi Banten yaitu $108 \mathrm{~km}$. Desa Cisarap memiliki luas wilayah $1.450 \mathrm{Ha}$, dengan pemanfaatan areal persawahan tadah hujan $1.129 \mathrm{Ha}$, perkebunan rakyat $94 \mathrm{Ha}$ 
dan dengan luas lahan pemukiman $75 \mathrm{Ha}$. Data dan potensi ekonomi Desa Cisarap sangat dipengaruhi oleh kondisi wilayah Desa yang sebagian besar dikelilingi oleh areal kehutanan dan perkebunan rakyat, adapun potensi Desa Cisarap yang ditinjau baik dari sumber daya manusia maupun sumber daya alam sampai saat ini potensi tersebut belum benar-benar optimal diberdayakan. Jumlah Kepala Keluarga di Desa Cisarap sebanyak 959 Kepala Keluarga dengan jumlah penduduk 3.261 Jiwa dan terdapat 519 Kepala Keluarga pra sejahtera.

Sedangkan mitra kedua pengabdian masyarakat adalah Desa Parungsari yang merupakan salah satu desa yang berada di wilayah Kecamatan Wanasalam Kabupaten Lebak dengan jarak $5 \mathrm{Km}$ dari Kecamatan Wanasalam. Desa Parungsari berbatasan langsung dengan :
a. Sebelah utara berbatasan dengan Desa Ketapang
b. Sebelah Selatan berbatasan dengan Desa Cisarap dan Desa Bejod
c. Sebelah Barat berbatasan dengan Desa Parungpanjang
d. Sebelah Timur berbatasan dengan Desa Cikeusik

Desa Parungsari memiliki memiliki jumlah penduduk sebanyak 2.963 jiwa, yang terdiri dari 633 KK masih kategori KK miskin .
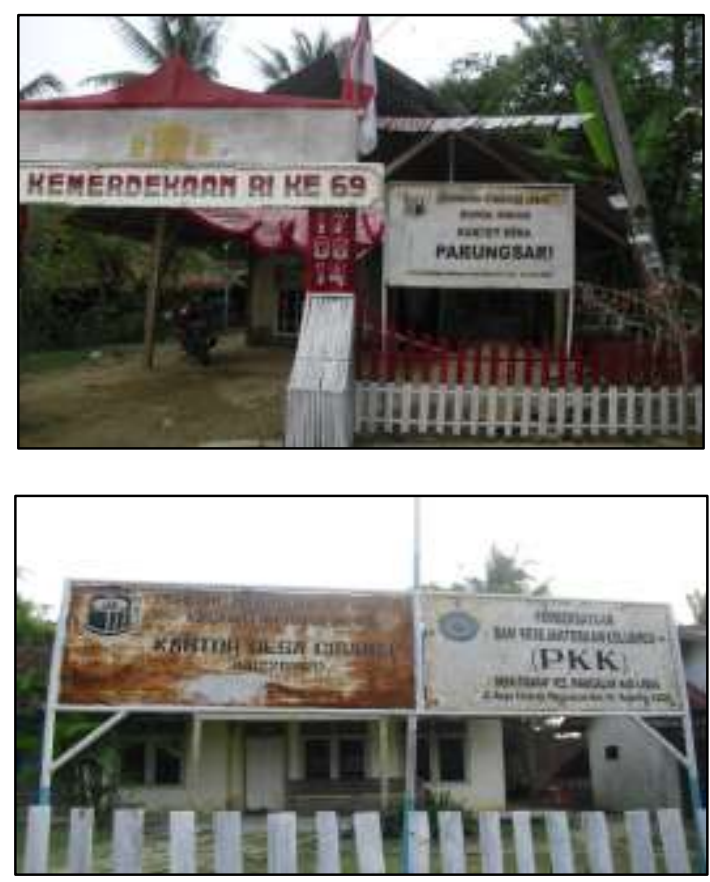

Gambar 1. Kantor Desa Parungsari dan Desa Cisarap

\section{Rumusan Masalah}

Berdasarkan analisis situasi melalui observasi, wawancara dan survey yang telah dilakukan terdapat berbagai permasalahan yang disepakati, diantaranya yaitu :

a. Formulasi kebijakan perencanaan pembangunan desa masih dirumuskan berdasarkan kepentingan jangka pendek dan tidak disusun berdasarkan identifikasi dan prioritas kebutuhan masyarakat;

b. Masih kuatnya kultur dan tradisi paternalistik kepala desa sebagai orang kuat dan berpengaruh dalam proses pengambilan keputusan dan kebijakan strategis dengan tidak melibatkan masyarakat desa secara aktif

c. Minimnya aktualisasi dan partisipasi masyarakat desa dalam pembuatan kebijakan perencanaan pembangunan yang berdampaknya pada minimnya pengawasan masyarakat terhadap kebijakan

d. Proses Musrenbang hanya dilakukan secara seremonial dan memposisikan masyarakat desa secara pasif dan sebagai pendengar dari program-program pembangunan yang telah digagas oleh aparat pemerintahan desa.

e. Minimnya pelaksanaan rembug warga sebagai forum dialog musyawarah dan perwujudan modal sosial masyarakat dalam membahas isu-isu strategis desa.

\section{METODE PELAKSANAAN KEGIATAN}

Penguatan Kapasitas Masyarakat berbasis inovasi formulasi kebijakan dilaksanakan melalui prinsipprinsip: (i)masyarakat adalah aktor utama perencana pembangunan dan diposisikan sebagai penentu/pengambil kebijakan; (ii)mengutamakan nilai-nilai kearifan lokal yang tercakup dalam modal sosial sesuai dengan karakteristik sosial, budaya dan potensi geografis; (iii)pemerintah desa adalah fasilitator yang memfasilitasi masyarakat desa dalam penyusunan inovasi formulasi kebijakan perencanaan pembangunan. Sedangkan Metode yang digunakan adalah Participatory Rapid Appraisal (PRA) atau penilaian desa secara partisipatif yang dilakukan melalui berbagai kegiatan sebagai berikut:

a. Pemetaan wilayah dan kegiatan yang terkait dengan topik penilaian keadaan;

b. Analisis keadaan yang berupa:

1) Keadaan masa lalu, sekarang dan kecenderungan di masa depan;

2) Identifikasi tentang perubahan-perubahan yang terjadi dan alasan-alasan atau penyebabnya;

3) Identifikasi (akar) masalah dan alternatifalternatif pemecahan masalah;

4) Kekuatan, kelemahan, peluang dan ancaman atau analisis strenght, weakness, 
opportunity and threat (SWOT) terhadap semua alternatif pemecahan masalah.

c. Pemilihan alternatif pemecahan masalah yang paling layak atau dapat dihandalkan (dapat dilaksanakan, efisien dan diterima oleh sistem sosialnya)

d. Rincian tentang stakeholders dan peran yang diharapkan dari para pihak, serta jumlah dan sumber-sumber pembiayaan yang dapat diharapkan untuk melaksanakan program kegiatan yang akan diusulkan/direkomendasikan.

Berdasarkan metode pemberdayaan masyarakat tersebut, pelaksanaan kegiatan pengabdian masyarakat ini akan dilaksanakan melalui tiga tahap yaitu tahap awal, tahap inti dan tahap akhir. Secara umum tahapan kegiatan pengabdian ini dapat dilihat pada Gambar 1. Berikut penjelasan pada masing-masing tahap kegiatan.

a. Tahap awal. Kegiatan pada tahap ini meliputi (a)observasi partisipatif dan survey. Dilakukan sebagai langkah awal untuk mengidentifikasi mengenai permasalahan di desa; (b)pemetaan wilayah desa, (c)merancang kegiatan inti berupa analisis keadaan dan pemilihan alternatif pemecahan masalah.

b. Tahap inti. Dalam tahap kedua ini, fokus kegiatan pengabdian masyarakat dilakukan proses pendampingan dan bimbingan melalui serangkaian kegiatan. Ada lima kegiatan yang akan diikuti oleh mitra, yaitu:

1) Sosialisasi identifikasi permasalahan;

2) Melakukan analisis keadaan yang berupa keadaan masa lalu, sekarang dan kecenderungan di masa depan melalui kegiatan forum warga tingkat desa;

3) Melakukan identifikasi tentang perubahanperubahan yang terjadi dan alasan-alasan atau penyebabnya;

4) Menyusun alternatif pemecahan masalah;

5) Melakukan analisis kekuatan, kelemahan, peluang dan ancaman atau analisis strenght, weakness, opportunity and threat (SWOT) terhadap semua alternatif pemecahan masalah;

6) Merumuskan pemilihan alternatif pemecahan masalah yang paling layak atau dapat dihandalkan;

7) Menyusun pembagian peran para stakeholders dan sumber-sumber pembiayaan yang dapat diharapkan untuk melaksanakan program kegiatan yang akan diusulkan/direkomendasikan.

c. Tahap akhir. Ada dua kegiatan dalam tahap ini yaitu (a)penyusunan inovasi formulasi kebijakan perencanan pembangunan; (b)sosialisasi inovasi formulasi kebijakan perencanaan pembangunan.

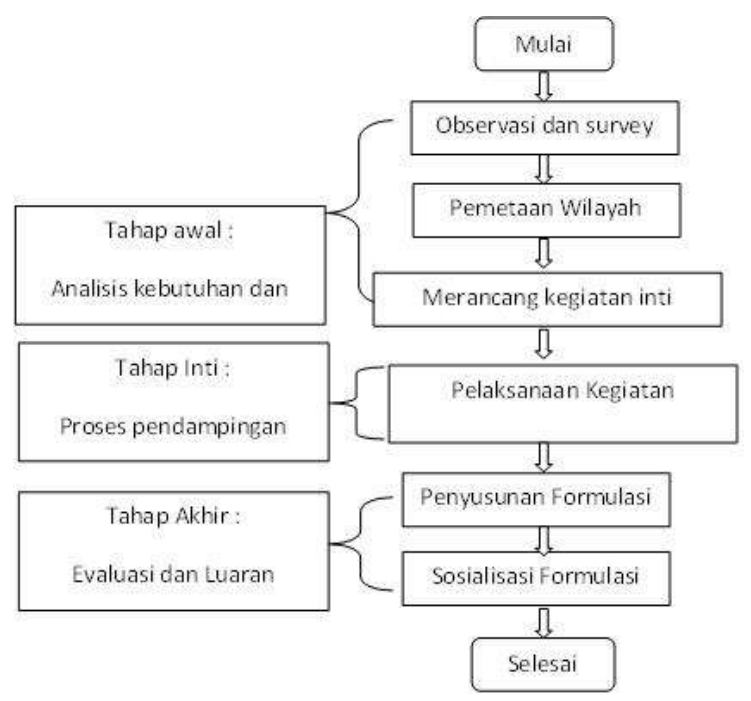

\section{Gambar 2. Bagan Tahapan Kegiatan Pengabdian Masyarakat}

\section{PEMBAHASAN}

Strategi penguatan kapasitas masyarakat mencakup pengorganisasian masyarakat desa, kelembagaan (organisasi, modal sosial dan institusi sosial), penguatan nilai-nilai sosial budaya dan penguatan kapasitas jaringan antar lembaga dalam masyarakat. Kegiatan pendampingan ini dilakukan selama 4 (bulan) bulan yaitu minggu kedua bulan Maret 2016 s/d minggu keempat bulan Juli 2016

Tahap Awal (Observasi dan Survey Partisipatif, Pemetaan wilayah desa, kelengkapan administrasi dan Merancang Kegiatan Inti)

a. Observasi dan survey partisipatif

Pada tahap ini kegiatan observasi dan survey dilakukan secara mandiri dengan melibatkan beberapa warga desa. Survey Dusun Mandiri (SDM) dilakukan secara berkelompok dan berpasangan untuk mengidentifikasi permasalahan dan kebutuhan masyarakat. Jumlah sampel pada kegiatan observasi dan survey pada Desa Cisarap dan Desa Parungsari menargetkan masing-masing sebanyak 100 kepala keluarga sedangkan jumlah wilayah yang diobservasi meliputi 4 (empat) dusun di Desa Cisarap dan 2 (dua) dusun di Desa Parungsari. Selanjutnya hasil observasi dan SDM tersebut diolah secara sederhana dengan membuat daftar identifikasi permasalahan dan kebutuhan masyarakat untuk kemudian didiskusikan pada kegiatan rembug warga masing-masing dusun. 
Sururi dan Mulyasih, Jurnal Pengabdian Masyarakat Wikrama Parahita 2017, Volume 1 Nomor 1: 5 - 18 DOI:

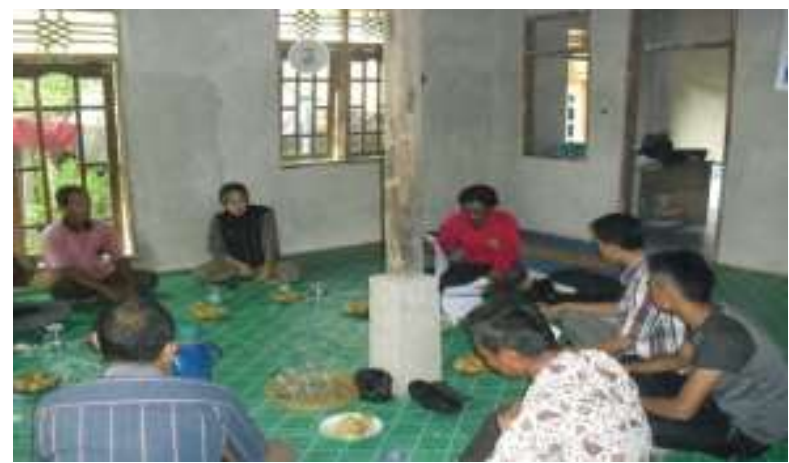

Gambar 3. Kegiatan Rembug Warga Desa Parungsari

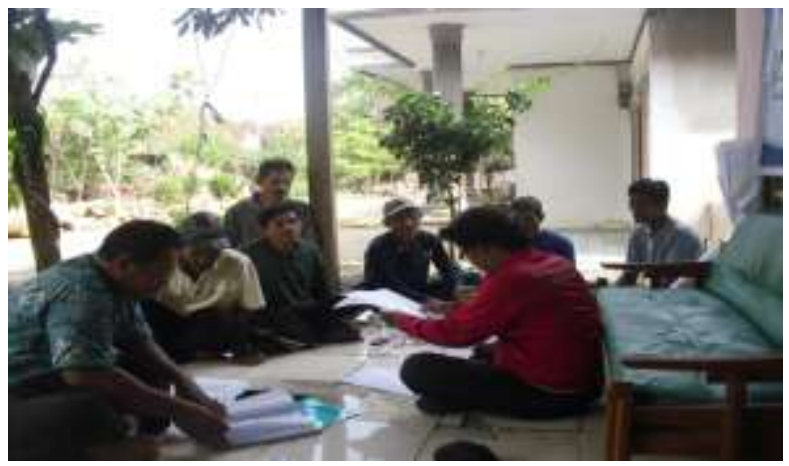

Gambar 4. Kegiatan Rembug Warga Desa Cisarap

b. Pemetaan Wilayah Desa (Batas wilayah, Sarana/prasarana dan potensi ekonomi)

1) Desa Cisarap

Tabel 3. Batas Wilayah

\begin{tabular}{lll}
\hline No & Batas Desa & Masukan dalam Peta \\
\hline \hline 1. & Sumber Daya Sarana dan Prasarana & $\begin{array}{l}\text { Jalan Desa, Mesjid, Musholla, Sekolah, Kantor } \\
\text { Desa }\end{array}$ \\
\hline 2. & Keadaan Fisik Lingkungan & $\begin{array}{l}\text { Persawahan, Tanah Kering, perkerasan, rabat } \\
\text { beton }\end{array}$ \\
\hline 3. & Luas dan tata Letak lahan termasuk Peruntukannya & $\begin{array}{l}\text { Sawah tadah hujan 1129 Ha, Pemukiman } \\
\text { Penduduk 75 Ha, Perkebunan 94 Ha }\end{array}$ \\
\hline 4. & Penyebaran Daerah Permukiman & Merata \\
\hline 5. & Aliran Air & Sungai Desa \\
\hline 6. & Lembaga yang ada di Desa & BPD, LPM, Karang Taruna \\
\hline 7. & Sekolah & RW 01, RW 02 \\
\hline 8. & Posyandu & RW.01, RW.02, RW 03 \\
\hline Sum
\end{tabular}

Sumber: RPJMD Desa Cisarap, 2014

Tabel 2. Data Kondisi Prasarana dan Sarana

\begin{tabular}{|c|c|c|c|c|}
\hline No & $\begin{array}{l}\text { Prasarana dan } \\
\text { Sarana }\end{array}$ & $\begin{array}{l}\text { Kondisi (sebutkan lokasi dan } \\
\text { data lainnya) }\end{array}$ & \begin{tabular}{llr}
$\begin{array}{l}\text { Masalah } \\
\text { lokasi } \\
\text { lainnya) }\end{array}$ & \multicolumn{2}{c}{ (sebutkan } \\
dan & data \\
\end{tabular} & $\begin{array}{l}\text { Potensi (sebutkan lokasi } \\
\text { dan data lainnya) }\end{array}$ \\
\hline 1. & Posyandu & $\begin{array}{l}\text { Fasilitas Kurang Memadai, } \\
\text { Lokasi RW 01-RW } 02\end{array}$ & $\begin{array}{l}\text { Minimnya } \\
\text { Kegiatan }\end{array}$ & $\begin{array}{l}\text { Pengurus dan bangunan } \\
\text { ada }\end{array}$ \\
\hline 2. & $\begin{array}{l}\text { Gedung } \\
\text { Sekolah }\end{array}$ & RW 01 & $\begin{array}{l}\text { Jaraknya jauh dari } \\
\text { dusun lainnya }\end{array}$ & Tenaga pengajar, SDM \\
\hline 3. & $\begin{array}{l}\text { Jalan Desa } \\
\text { Perkerasan }\end{array}$ & $\begin{array}{l}\text { Dari total } 13.35 \mathrm{Km}, 11.5 \mathrm{Km} \\
\text { rusak berat }\end{array}$ & $\begin{array}{l}\text { Mengganggu aktivitas } \\
\text { masyarakat }\end{array}$ & Lahan, tenaga kerja \\
\hline
\end{tabular}

Sumber: RPJMD Desa Cisarap, 2014

2) Desa Parungsari

Tabel 3. Batas Wilayah

\begin{tabular}{lll}
\hline No & Batas Desa & Masukan dalam Peta \\
\hline \hline 1. & Sumber Daya Sarana dan Prasarana & $\begin{array}{l}\text { Jalan Desa, Mesjid, Musholla, Sekolah, } \\
\text { Kantor Desa }\end{array}$ \\
\hline 2. & Keadaan Fisik Lingkungan & Persawahan, Tanah Kering, perkerasan, \\
\hline
\end{tabular}


Sururi dan Mulyasih, Jurnal Pengabdian Masyarakat Wikrama Parahita 2017, Volume 1 Nomor 1: 5 - 18 DOI:

\begin{tabular}{lll}
\hline & & \\
\hline 3. & Luas dan tata Letak lahan termasuk Peruntukannya & rabat beton \\
& & $\begin{array}{l}\text { Pertanian sawah teririgasi 98 Ha, tadah } \\
\text { hujan 243 Ha, ladang 195 Ha, Pemukiman } \\
\text { Penduduk 72 Ha, Perkebunan 167 Ha }\end{array}$ \\
\hline 4. & Penyebaran Daerah Permukiman & Merata \\
\hline 5. & Aliran Air & Kering \\
\hline 6. & Lembaga yang ada di Desa & BPD, LPM, Karang Taruna \\
\hline 7. & Sekolah & RW 01, RW 02 \\
\hline \hline
\end{tabular}

Sumber: RPJMD Desa Parungsari, 2014

Tabel 4. Kondisi Sarana dan Prasarana

\begin{tabular}{|c|c|c|c|c|}
\hline No & Prasarana dan Sarana & $\begin{array}{l}\text { Kondisi (sebutkan lokasi } \\
\text { dan data lainnya) }\end{array}$ & $\begin{array}{l}\text { Masalah (sebutkan lokasi } \\
\text { dan data lainnya) }\end{array}$ & $\begin{array}{l}\text { Potensi (sebutkan } \\
\text { lokasi dan data } \\
\text { lainnya) }\end{array}$ \\
\hline 1. & Posyandu & $\begin{array}{l}\text { Fasilitas Kurang Memadai, } \\
\text { Lokasi RW 01-RW } 02\end{array}$ & Minimnya Dana Kegiatan & $\begin{array}{l}\text { Pengurus dan } \\
\text { bangunan ada }\end{array}$ \\
\hline 2. & Pemagaran TPU & $\begin{array}{l}\text { Belum ada batas pemisah, } \\
\text { Lokasi RW. } 02 \text {. }\end{array}$ & $\begin{array}{l}\text { Banyaknya binatang } \\
\text { masuk, bangunan rusak }\end{array}$ & $\begin{array}{l}\text { Pengurus TPU dan } \\
\text { Lahan ada }\end{array}$ \\
\hline 3. & Gedung Sekolah & RW 01-RW02 & $\begin{array}{l}\text { Gedung sekolah bocor } \\
\text { jika terjadi hujan }\end{array}$ & $\begin{array}{l}\text { Tenaga pengajar, } \\
\text { SDM }\end{array}$ \\
\hline
\end{tabular}

Sumber : RPJMD Desa Parungsari, 2014

Tabel 3. Peta, profil masalah dan Potensi ekonomi masyarakat Desa Cisarap dan Desa Parungsari

\begin{tabular}{lllll}
\hline & & & \multicolumn{2}{l}{ Profil dan Karakteristik Masalah } \\
\cline { 3 - 5 } No Potensi Ekonomi Desa & $\begin{array}{l}\text { Akses Usaha } \\
\text { Pasalah }\end{array}$ & $\begin{array}{l}\text { (pemasaran, } \\
\text { bahan } \\
\text { baku,pabrik dII) }\end{array}$ & Akses Modal & $\begin{array}{l}\text { Kelembagaan } \\
\text { Ekonomi/Keuangan }\end{array}$ \\
\hline \hline 1. Pertanian & $\begin{array}{l}\text { Pelatihan } \\
\text { Keterampilan }\end{array}$ & $\begin{array}{l}\text { Kualitas hasil Belum ada Kurangnya pelatihan } \\
\text { produksi kurang bantuan } \\
\text { bisa bersaing }\end{array}$ & $\begin{array}{l}\text { Usaha } \\
\text { kegiatan }\end{array}$ \\
\hline \hline
\end{tabular}

Sumber : Survey Desa Mandiri (SDM), 2016

c. Merancang Kegiatan Inti

Pada tahap ini dilakukan penyusunan draft analisis keadaan dan pemilihan alternatif pemecahan masalah dan pembagian peran para pihak yang sesuai dengan kebutuhan mitra dan sebagai solusi dari permasalahan yang dihadapi. Kegiatan yang dilaksanakan Tim Pengabdian Masyarakat bersama-sama masyarakat adalah melakukan rembug warga dusun. Pelaksanaan rembug warga di tiap-tiap dusun dihadiri rata-rata sekitar 25 orang. Output dari kegiatan ini adalah terbentuknya Organisasi Masyarakat Mandiri Dusun (Ormandus) sebagai representasi masyarakat di tiap-tiap dusun dalam penyusunan formulasi kebijakan perencanaan pembangunan.
Ormandus adalah organisasi ditingkat dusun yang mempunyai tugas dan tanggung jawab mewakili masyarakat dusun, menjadi penanggungjawab rembug-rembug dan musyawarah warga dusun dan memastikan kegiatan perencanaan pembangunan berjalan sesuai dengan yang telah direncanakan. dalam memastikan setiap kebijakan desa. Dengan jumlah kepala keluarga di tiap desa yang sangat banyak, maka kebutuhan untuk menyusun Ormandus dirasakan penting. Fokus kegiatan organisasi lokal Ormandus yang telah dibentuk adalah menyusun formulasi kebijakan perencanaan pembangunan dengan berbasis pada konsep Ketahui, Kelola, Kawal atau 3K sebagai langkah-langkah inovasi formulasi kebijakan perencanaan pembangunan desa. 


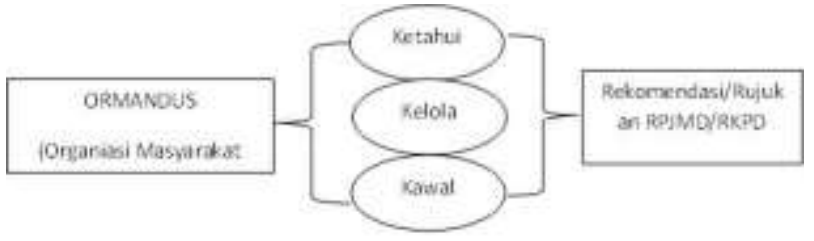

Gambar 5. Strategi Penguatan Kapasitas Masyarakat

Sumber : Analisis Penyusun, 2016

Tahap inti. Dalam tahap ini, fokus pengabdian masyarakat dilakukan melalui kegiatan pendampingan dan bimbingan melalui serangkaian kegiatan. Ada lima kegiatan yang diikuti oleh mitra pengabdian masyarakat bersama tim, yaitu:

a. Sosialisasi Identifikasi Permasalahan dan

Kebutuhan Masyarakat

Secara umum identifikasi permasalahan dan kebutuhan masyarakat di kedua Desa relatif sama, hal ini dimungkinkan karena jarak kedua desa berdekatan dan mempunyai kecenderungan permasalahan yang sama. Hasil identifikasi pada kegiatan rembug warga di tiap-tiap desa adalah sebagai berikut :

\begin{tabular}{|c|c|}
\hline $\begin{array}{l}\text { Identifikasi } \\
\text { Permasalahan Utama }\end{array}$ & Lokasi Desa \\
\hline $\begin{array}{lll}\text { Jalan } & \text { Berlubang } & \text { dan } \\
\text { Becek } & & \\
\end{array}$ & Desa Cisarap \\
\hline $\begin{array}{l}\text { Jembatan Penghubung } \\
\text { antar Kampung rusak }\end{array}$ & Desa Cisarap \\
\hline $\begin{array}{l}\text { Akse dan Kondisi jalan ke } \\
\text { rumah warga masih tanah }\end{array}$ & $\begin{array}{l}\text { Desa Parungsari } \\
\text { dan Desa Cisarap }\end{array}$ \\
\hline $\begin{array}{ll}\text { Sebagian } & \text { besar } \\
\text { masyarakat } & \text { belum } \\
\text { memiliki MCK } & \end{array}$ & $\begin{array}{l}\text { Desa Cisarap dan } \\
\text { Desa Parungsari }\end{array}$ \\
\hline $\begin{array}{lr}\text { Sebagian } & \text { besar } \\
\text { masyarakat } & \text { belum } \\
\text { mendapatkan akses listrik }\end{array}$ & Desa Cisarap \\
\hline $\begin{array}{l}\text { Belum ada Penerangan } \\
\text { Jalan Umum (PJU) }\end{array}$ & Desa Cisarap \\
\hline $\begin{array}{l}\text { Sarana Pendidikan SD dan } \\
\text { PAUD sudah rusak }\end{array}$ & $\begin{array}{l}\text { Desa Cisarap dan } \\
\text { Desa Parungsari }\end{array}$ \\
\hline
\end{tabular}

b. Melakukan analisis keadaan yang berupa keadaan masa lalu, sekarang dan kecenderungan di masa depan melalui kegiatan forum warga tingkat desa;

\begin{tabular}{|c|c|c|c|}
\hline \multirow[t]{2}{*}{ Keadaan Masa Lalu } & \multicolumn{2}{|l|}{ Keadaan Sekarang } & \multirow[t]{2}{*}{ Keadaan masa depan } \\
\hline & Desa Cisarap & Desa Parungsari & \\
\hline 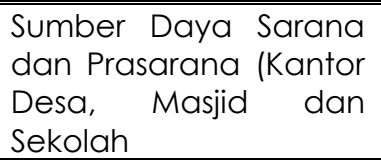 & $\begin{array}{l}\text { Memerlukan } \\
\text { rehabilitasi terutama } \\
\text { sekolah PAUD dan SD }\end{array}$ & Secara umum baik & $\begin{array}{ll}\text { Kondisi sarana } & \text { dan } \\
\text { prasarana } & \text { yang } \\
\text { memadai } & \text { bag } \\
\text { kebutuhan warga } & \\
\end{array}$ \\
\hline $\begin{array}{l}\text { Keadaan } \\
\text { Lingkungan }\end{array}$ & $\begin{array}{l}\text { Diperlukan penataan } \\
\text { kawasan lingkungan } \\
\text { yang sehat dan } \\
\text { nyaman }\end{array}$ & $\begin{array}{l}\text { Diperlukan penataan } \\
\text { kawasan lingkungan yang } \\
\text { sehat dan nyaman }\end{array}$ & $\begin{array}{l}\text { Kondisi fisik lingkungan } \\
\text { yang sehat dan } \\
\text { nyaman terutama } \\
\text { untuk anak-anak dan } \\
\text { perempuan }\end{array}$ \\
\hline $\begin{array}{l}\text { Luas dan tata Letak } \\
\text { lahan termasuk } \\
\text { Peruntukannya }\end{array}$ & $\begin{array}{l}\text { Luas dan letak lahan } \\
\text { belum dimanfaatkan } \\
\text { secara optimal oleh } \\
\text { masyarakat }\end{array}$ & $\begin{array}{l}\text { Luas dan letak lahan belum } \\
\text { dimanfaatkan secara optimal } \\
\text { oleh masyarakat }\end{array}$ & $\begin{array}{l}\text { Pemanfataan luas dan } \\
\text { tata letak lahan }\end{array}$ \\
\hline $\begin{array}{l}\text { Penyebaran } \\
\text { Permukiman }\end{array}$ & Merata & Merata & \begin{tabular}{ll} 
& \multicolumn{2}{l}{ Mempertahankan } \\
penyebaran daerah \\
permukiman sepert \\
saat ini
\end{tabular} \\
\hline Aliran Air & Kering & Ada sungai desa & $\begin{array}{l}\text { Pemanfaatan sunga } \\
\text { desa }\end{array}$ \\
\hline $\begin{array}{l}\text { Lembaga yang ada di } \\
\text { Desa }\end{array}$ & $\begin{array}{l}\text { BPD, LPM dan Karang } \\
\text { Taruna }\end{array}$ & BPD, LPM dan Karang Taruna & Tetap dipertahankan \\
\hline
\end{tabular}


c. Melakukan identifikasi tentang perubahan-perubahan yang terjadi dan alasan-alasan atau penyebabnya;

1) Desa Parungsari

\begin{tabular}{|c|c|c|}
\hline No & Perubahan-perubahan yang terjadi & Alasan penyebab \\
\hline 1 & Jumlah Penduduk meningkat & $\begin{array}{l}\text { Sampai dengan tahun } 2014 \text { berjumlah } 2.963 \text {, dan tahun } 2016 \\
\text { berjumlah } 3154 \text {. Hal tersebut disebabkan karena adanya } \\
\text { peningkatan jumlah kedatangan penduduk yang menetap } \\
\text { dan menigkatnya jumlah kelahiran }\end{array}$ \\
\hline 2 & $\begin{array}{l}\text { Jumlah Keluarga Pra KS masih tinggi } \\
\text { dan belum terjadi peningkatan } \\
\text { secara signifikan }\end{array}$ & $\begin{array}{l}\text { Akses masyarakat terhadap sumber daya pembangunan } \\
\text { masih rendah }\end{array}$ \\
\hline 3 & Jumlah RT dan RW berubah & $\begin{array}{l}\text { Dari keadaan geografis Desa Parungsari yang memiliki } 10 \\
\text { Rukun Tetangga dan } 2 \text { Dusun, dengan kondisi antar Dusun } \\
\text { yang tersebar, dan merupakan kawasan pertanian serta } \\
\text { akses untuk masing-masing Kampung memiliki kesulitan } \\
\text { karena kondisi jalan yang masih berupa tanah yang tidak } \\
\text { didukung sarana jalan yang baik. }\end{array}$ \\
\hline 4 & $\begin{array}{l}\text { Potensi Desa belum dimanfaatkan } \\
\text { secara optimal }\end{array}$ & $\begin{array}{l}\text { Dari segi ekonomi yaitu bidang pertanian dimana mereka } \\
\text { memiliki keterbatasan dalam hal meningkatkan hasil-hasil } \\
\text { pertanian maupun dalam hal memasarkan hasil pertanian } \\
\text { tersebut, hal tersebut disebabkan terbatasnya modal dan } \\
\text { akses pemasaran }\end{array}$ \\
\hline
\end{tabular}

Sumber: Survey Desa Mandiri, 2016

2) Desa Cisarap

\begin{tabular}{|c|c|c|}
\hline No & Perubahan-perubahan yang terjadi & Alasan penyebab \\
\hline 1 & Jumlah Penduduk meningkat & $\begin{array}{l}\text { Sampai dengan tahun } 2014 \text { berjumlah } 3.261 \text {, dan tahun } 2016 \\
\text { berjumlah } 3.456 \text {. Hal tersebut disebabkan karena adanya } \\
\text { peningkatan jumlah kedatangan penduduk yang menetap } \\
\text { dan menigkatnya jumlah kelahiran }\end{array}$ \\
\hline 2 & $\begin{array}{l}\text { Jumlah Keluarga Pra KS masih tinggi } \\
\text { dan belum terjadi peningkatan } \\
\text { secara signifikan }\end{array}$ & $\begin{array}{l}\text { Akses masyarakat terhadap sumber daya pembangunan } \\
\text { masih rendah }\end{array}$ \\
\hline 3 & Jumlah RT dan RW berubah & $\begin{array}{l}\text { Dari keadaan geografis Desa Cisarap yang memiliki } 4 \text { (Empat) } \\
\text { Dusun, dengan kondisi antar Dusun yang tersebar, dan } \\
\text { merupakan kawasan pertanian serta akses untuk masing- } \\
\text { masing kampung memiliki kesulitan karena kondisi jalan yang } \\
\text { masih berupa tanah yang tidak didukung sarana jalan yang } \\
\text { baik. }\end{array}$ \\
\hline 4 & $\begin{array}{l}\text { Potensi Desa belum dimanfaatkan } \\
\text { secara optimal }\end{array}$ & $\begin{array}{l}\text { Dari segi ekonomi yaitu bidang pertanian dimana mereka } \\
\text { memiliki keterbatasan dalam hal meningkatkan hasil-hasi } \\
\text { pertanian maupun dalam hal memasarkan hasil pertanian } \\
\text { tersebut, hal tersebut disebabkan terbatasnya modal, } \\
\text { minimnya sarana dan prasarana pertanian dan akses } \\
\text { pemasaran }\end{array}$ \\
\hline
\end{tabular}

Sumber: Survey Desa Mandiri, 2016 
d. Menyusun alternatif pemecahan masalah

1) Desa Parungsari

\begin{tabular}{lll}
\hline No & Permasalahan & Alternatif Pemecahan Masalah \\
\hline \hline 1 & $\begin{array}{l}\text { Akses dan Kondisi jalan ke rumah warga masih } \\
\text { tana }\end{array}$ & Pembangunan Paving Block \\
\hline 2 & Sebagian besar masyarakat belum memiliki MCK & Pembangunan MCK di tiap rumah/MCK umum \\
\hline 3 & Sarana Pendidikan SD dan PAUD sudah rusak & Rehabilitasi gedung SD dan PAUD \\
\hline \hline
\end{tabular}

Sumber : Survey Desa Mandiri, 2016

2) Desa Cisarap

\begin{tabular}{|c|c|c|}
\hline No & Permasalahan & Alternatif Pemecahan Masalah \\
\hline 1 & Jalan Berlubang dan Becek & Pembangunan Jalan telford \\
\hline 2 & $\begin{array}{l}\text { Jembatan Penghubung antar Kampung } \\
\text { rusak }\end{array}$ & Rehabilitasi Jembatan \\
\hline 3 & $\begin{array}{l}\text { Akses dan Kondisi jalan ke rumah warga } \\
\text { masih tanah }\end{array}$ & Pembangunan Paving Block \\
\hline 4 & $\begin{array}{l}\text { Sebagian besar masyarakat belum } \\
\text { memiliki MCK }\end{array}$ & Pembangunan MCK di tiap rumah/MCK umum \\
\hline 5 & $\begin{array}{l}\text { Sebagian besar masyarakat belum } \\
\text { mendapatkan akses listrik }\end{array}$ & Pembangunan gardu listrik \\
\hline 6 & Belum ada Penerangan Jalan Umum (PJU) & Pembangunan PJU di tiap kampung dan dusun \\
\hline 7 & $\begin{array}{l}\text { Sarana Pendidikan SD dan PAUD sudah } \\
\text { rusak }\end{array}$ & Rehabilitasi gedung SD dan PAUD \\
\hline
\end{tabular}

Sumber : Survey Desa Mandiri, 2016

e. Melakukan analisis kekuatan, kelemahan, peluang dan ancaman atau analisis strenght, weakness, opportunity and threat (SWOT).

1) Desa Parungsari

\begin{tabular}{ll}
\hline Strenght (Kekuatan) & Weakness (Kelemahan) \\
\hline \hline Modal sosial masyarakat & Kondisi dan akses jalan ke pemukiman \\
Luas lahan dan tata letak desa cukup representatif & $\begin{array}{l}\text { Warga masih berupa tanah } \\
\text { Bungunan sekolah rusak }\end{array}$ \\
Pusat ekonomi strategis & $\begin{array}{l}\text { Sebagian masyarakat belum mempunyai } \\
\text { MCK }\end{array}$ \\
\hline Opportunity (Peluang) & Threat (Ancaman) \\
\hline Kelompok Tani & Jumlah Keluarga miskin/ pra sejahtera \\
Kader Pengurus & masih tinggi \\
Tingkat pendidikan masyarakat dalam baca tulis cukup baik & $\begin{array}{l}\text { Minimnya kemampuan masyarakat dalam } \\
\text { memanfaatkan potensi ekonomi }\end{array}$ \\
\hline \hline
\end{tabular}

2) Desa Cisarap

\begin{tabular}{ll}
\hline Strenght (Kekuatan) & Weakness (Kelemahan) \\
\hline \hline $\begin{array}{l}\text { Modal sosial masyarakat } \\
\text { Luas lahan dan tata letak desa } \\
\text { Jumlah penduduk usia Produktif } \\
\text { Motivasi masyarakat cukup tinggi }\end{array}$ & $\begin{array}{l}\text { Kendisi dan akses jalan ke pemukiman warga masih berupa tanah } \\
\text { Sebagian masyarakat belum mempunyai MCK }\end{array}$ \\
\hline Opportunity (Peluang) & Threat (Ancaman) \\
\hline Kelompok Tani & Jumlah Keluarga miskin/ pra sejahtera masih tinggi \\
Sumber daya lokal & Tingkat kriminialitas cukup tinggi \\
Kader Pengurus & Minimnya kemampuan masyarakat dalam memanfaatkan potensi \\
& ekonomi \\
\hline
\end{tabular}


f. Merumuskan pemilihan alternatif pemecahan masalah yang paling layak atau dapat dihandalkan.

Pada tahap ini, rembug desa dilakukan dengan mengundang berbagai pihak terkait seperti Kepala
Desa, Ketua BPD, Tokoh masyarakat, kader PKK dan masyarakat secara umum. Tujuan kegiatan ini adalah menginventarisir prioritas kebutuhan usulan kegiatan tersebut dalam sebuah analisis pemetaan perencanaan pembangunan sebagai berikut :

\section{Tabel 4. Analisis Nilai dari kebutuhan dan Usulan Kegiatan}

\section{Desa Parungsari}

a. Pembangunan Paving Block

b. Pembangunan MCK

c. Rehabilitasi Gedung SD dan PAUD

\begin{tabular}{|c|c|c|c|c|c|}
\hline \multirow[t]{2}{*}{ No } & \multirow[t]{2}{*}{ Aspek Penilaian } & \multicolumn{4}{|c|}{$\begin{array}{l}\text { Nilai Kebutuhan dan Usulan } \\
\text { Kegiatan }\end{array}$} \\
\hline & & & 1 & 2 & 3 \\
\hline \multirow[t]{2}{*}{1} & $\begin{array}{l}\text { Kegiatan pembangunan meningkatkan kualitas dan akses } \\
\text { terhadap pelayanan dasar }\end{array}$ & & & & \\
\hline & $\begin{array}{l}A=\text { Iya } \\
B=\text { Kurang } \\
C=\text { Tidak }\end{array}$ & $\begin{array}{l}A=3 \\
B=1\end{array}$ & 3 & 3 & 3 \\
\hline \multirow[t]{2}{*}{2} & $\begin{array}{l}\text { Kegiatan pembangunan mendukung peningkatan ekonomi } \\
\text { masyarakat secara produktif }\end{array}$ & & & & \\
\hline & $\begin{array}{l}\mathrm{A}=\text { Sangat mendukung } \\
\mathrm{B}=\text { Kurang Mendukung } \\
\mathrm{C}=\text { Tidak mendukung }\end{array}$ & $\begin{array}{l}A=3 \\
B=2 \\
C=1\end{array}$ & 3 & 2 & 2 \\
\hline \multirow[t]{2}{*}{3} & $\begin{array}{l}\text { Kegiatan pembangunan melibatkan masyarakat setempat } \\
\text { secara langsung }\end{array}$ & & & & \\
\hline & $\begin{array}{l}\mathrm{A}=\text { Melibatkan } \\
\mathrm{B}=\text { Tidak Melibatkan }\end{array}$ & $\begin{array}{l}A=2 \\
B=1\end{array}$ & 3 & 2 & 2 \\
\hline \multirow[t]{2}{*}{4} & $\begin{array}{l}\text { Manfaat pembangunan dirasakan secara langsung oleh } \\
\text { masyarakat desa setempat }\end{array}$ & & & & \\
\hline & $\begin{array}{l}A=\text { Dirasakan } \\
B=\text { Kurang dirasakan }\end{array}$ & $\begin{array}{l}A=2 \\
B=1\end{array}$ & 2 & 2 & 2 \\
\hline \multirow[t]{2}{*}{5} & Lahan yang akan digunakan merupakan milik umum/desa & & & & \\
\hline & $\begin{array}{l}A=\text { Milik Desa } \\
B=\text { Bukan Milik Desa }\end{array}$ & $\begin{array}{l}A=2 \\
B=1\end{array}$ & 3 & 3 & 3 \\
\hline \multirow[t]{2}{*}{6} & $\begin{array}{l}\text { Besarnya biaya pembangunan dapat dijangkau oleh } \\
\text { anggaran desa }\end{array}$ & & & & \\
\hline & $\begin{array}{l}\mathrm{A}=\text { Dapat dijangkau } \\
\mathrm{B}=\text { Tidak dapat dijangkau }\end{array}$ & $\begin{array}{l}A=2 \\
B=1\end{array}$ & 2 & 2 & 2 \\
\hline \multirow[t]{2}{*}{7} & $\begin{array}{l}\text { Pembangunan yang dilaksanakan menggunakan teknologi } \\
\text { sederhana berdasarkan kemampuan teknis dan sumber daya } \\
\text { lokal yang tersedia }\end{array}$ & & & & \\
\hline & $\begin{array}{l}\text { A }=\text { Teknologi sederhana dan dapat diterapkan } \\
B=\text { Teknologi tinggi dan tidak dapat dterapkan }\end{array}$ & $\begin{array}{l}A=2 \\
B=1\end{array}$ & 2 & 2 & 2 \\
\hline \multirow[t]{4}{*}{8} & Waktu pelaksanaan pembangunan & & & & \\
\hline & $\begin{array}{l}\mathrm{A}=<3 \text { bulan } \\
\mathrm{B}=>3 \text { bulan }\end{array}$ & $\begin{array}{l}A=2 \\
B=1\end{array}$ & 2 & 2 & 2 \\
\hline & Total Nilai & & 20 & 16 & 16 \\
\hline & Peringkat & & 1 & 2 & 2 \\
\hline
\end{tabular}

Berdasarkan tabel 4 tersebut dapat dijelaskan bahwa nilai kebutuhan dan usulan kegiatan yang mendapatkan peringkat pertama dan memperoleh nilai tertinggi 20 adalah pembangunan jalan paving block untuk memudahkan akses masyarakat ke daerah pemukiman. Sedangkan pembangunan MCK dan rehabilitasi gedung sekolah masingmasing mendapatkan nilai 16. 


\section{Tabel 5. Analisis Nilai dari kebutuhan dan Usulan Kegiatan}

\section{Desa Cisarap}

a. Pembangunan Jalan Telford

b. Rehabilitasi Jembatan

c. Pembangunan Paving Block

d. Pembangunan MCK

e. Pembangunan gardu listrik

f. Pembangunan JPU

g. Rehabilitasi Gedung SD dan PAUD

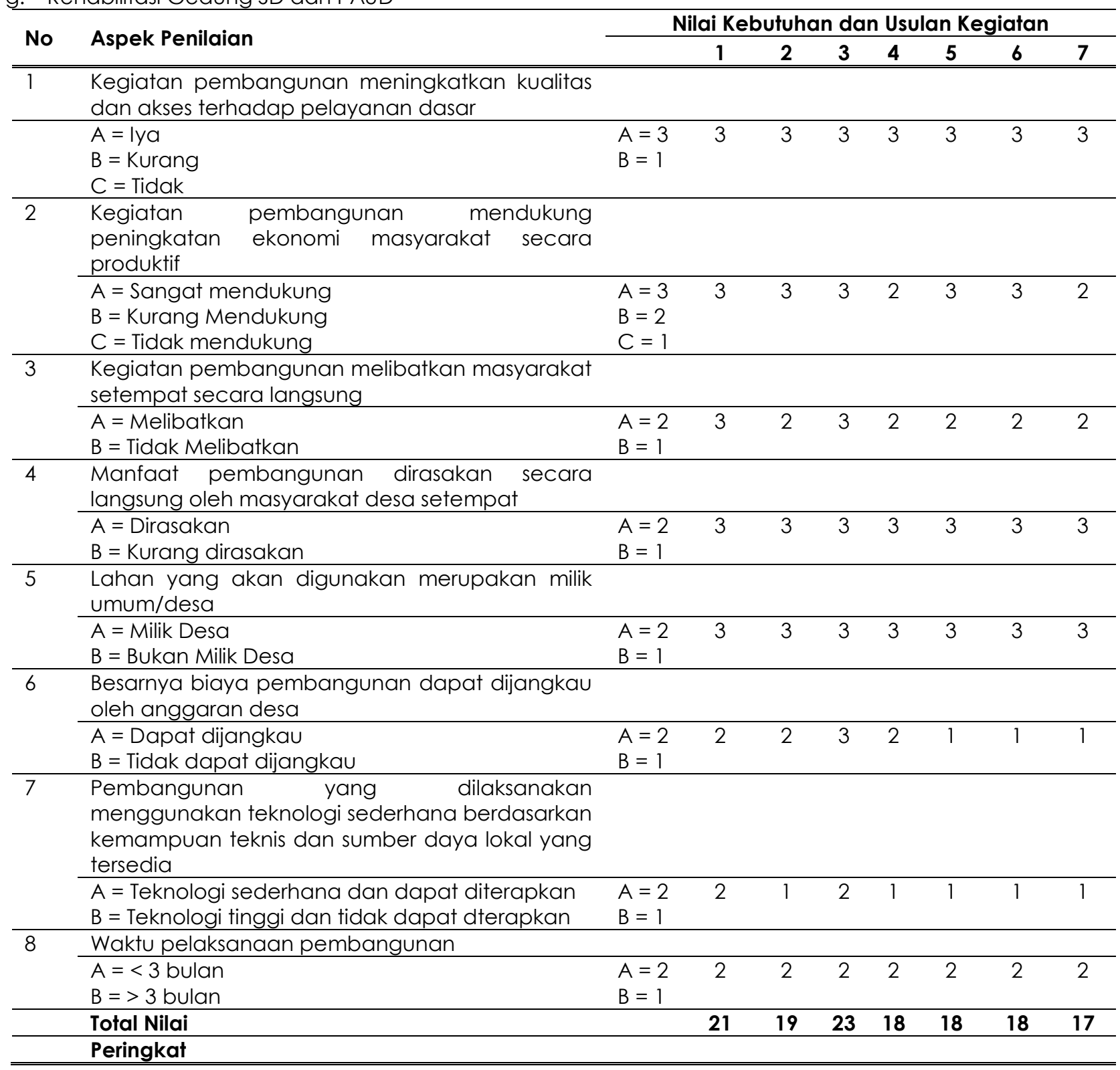

Berdasarkan tabel 5 tersebut dapat dijelaskan bahwa nilai kebutuhan dan usulan kegiatan yang mendapatkan peringkat pertama dan memperoleh nilai tertinggi 23 adalah pembangunan jalan Paving
Block. Sedangkan pembangunan jalan telford berada di peringkat kedua dengan nilai 21 dan rehabilitasi jembatan berada di peringkat 3 dengan nilai 19 
Tahap akhir. Ada dua kegiatan dalam tahap ini yaitu (a)penyusunan formulasi kebijakan perencanan pembangunan; (b)sosialisasi inovasi kebijakan perencanaan pembangunan

a. Penyusunan Inovasi formulasi Kebijakan perencanaan pembangunan

Pada tahap ini diselenggarakan musyawarah tingkat desa dengan mengundang warga tiap-tiap dusun untuk bersama-sama menyusun dokumen perencanaan pembangunan berdasarkan tahapan kegiatan yang telah dilaksanakan yang selanjutnya menjadi dokumen formulasi kebijakan perencanaan pembangunan desa yang berkelanjutan dan diserahkan ke pemerintah desa sebagai bahan rekomendasi/rujukan RPJMD dan RKPD.

Pembagian peran stakeholders dalam pelaksanaan program kegiatan difasilitasi oleh Ormandus sebagai representasi masyarakat tiap-tiap dusun yang selanjutnya akan mensosialisasikan hasil kegiatan penilaian desa secara partisipatif kepada masyarakat melalui spanduk, info selebaran yang dibagikan kepada seluruh masyarakat dan papan pengumuman informasi di tiap-tiap dusun dan kantor desa.

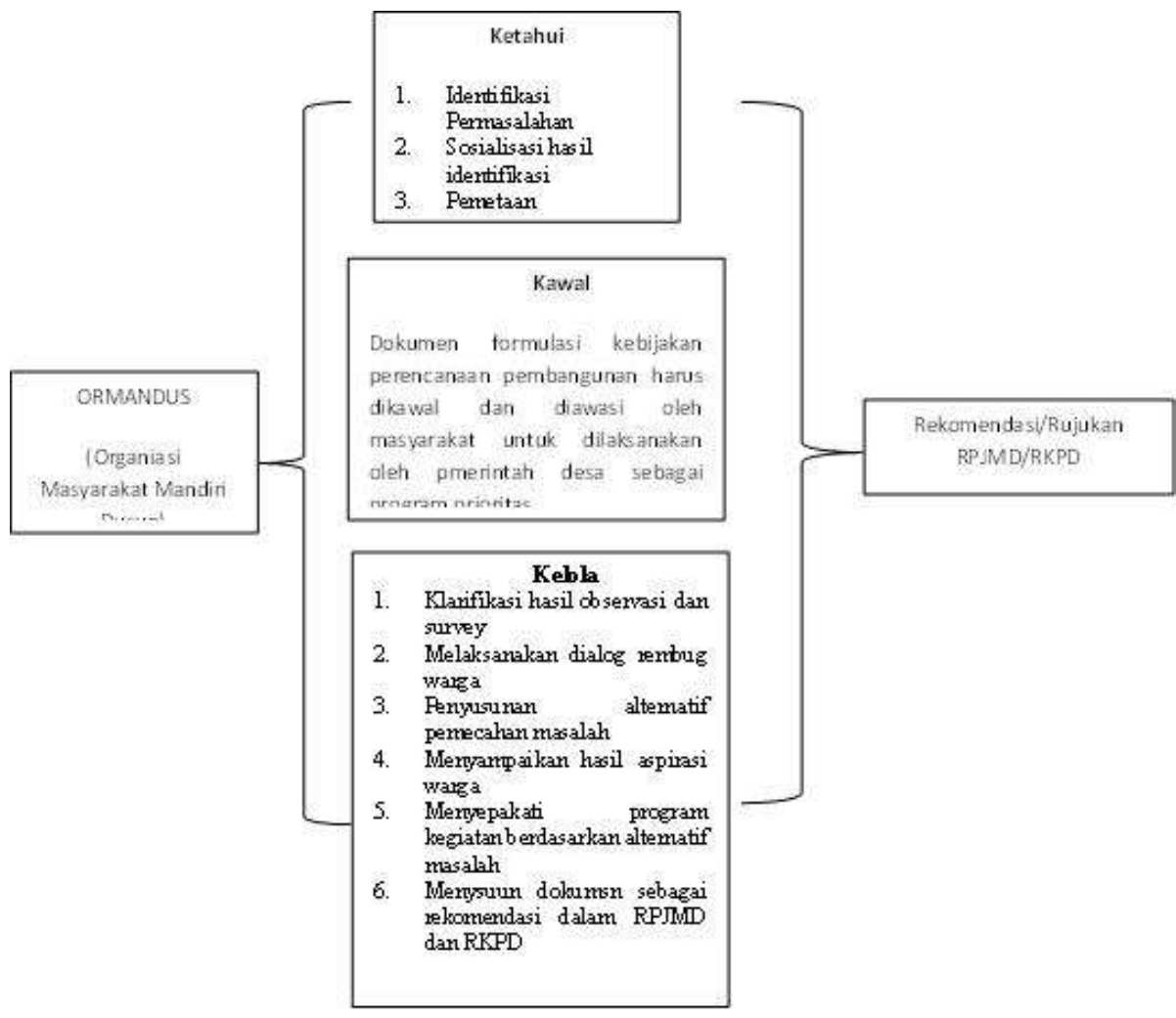

Gambar 6. Pengembangan Strategi Penguatan Kapasitas Masyarakat melalui Inovasi formulasi kebijakan berbasis $3 \mathrm{~K}$

sumber : Analisis Penyusun, 2016

\section{KESIMPULAN DAN SARAN}

\section{a. Kesimpulan}

Dari kegiatan yang telah dilaksanakan, dapat disimpulkan beberapa hal sebagai berikut :

1) Masyarakat Desa Parungari dan Desa Cisarap sebagai mitra pengabdian masyarakat memiliki antusias yang sangat besar terutama dalam proses pendampingan perencanaan pembangunan walaupun dengan segala keterbatasan yang dimiliki. Hal tersebut dapat terlihat dari jumlah kehadiran masyarakat dalam kegiatan Survey Desa Mandiri (SDM) berjumlah 8-10 orang dengan target observasi dan survey sebanyak 100 Kepala Keluarga, terealisasi 73 Kepala Keluarga.

2) Kegiatan rembug warga tiap-tiap dusun mendapatkan respon yang positif dari sebagian masyarakat. Sebagai desa yang sebagian besar masih tergolong kurang sejahtera/miskin, respon masyarakat dalam mengikuti program pendampingan perlu mendapatkan apresiasi sebagai bagian dari upaya kesadaran 
masyarakat tentang pentingnya perencanaan pembangunan yang dirancang dari, oleh dan untuk masyarakat.

3) Kegiatan pengabdian masyarakat masyarakat antara tim pengabdian bersama-sama masyarakat di Desa Cisarap dan Desa Parungsari melalui kegiatan perencanaan pembangunan melalui inovasi formulasi kebijakan berjalan sesuai dengan rencana dan target yang telah ditetapkan. Tahapantahapan kegiatan pendampingan berjalan dengan cukup baik mulai dari sosialisasi, observasi dan survey, identifikasi, analisis pemecahan masalah serta penyusunan dokumen perencanaan pembangunan untuk diserahterimakan kepada pemerintah desa sebagai bahan rekomendasi/rujukan penyusunan RPJMD dan RKPD.

b. Saran

Adapun saran-saran dalam kegiatan ini adalah :

1) Dalam mendorong perencanaan pembangunan yang partisipatif dan aspiratif, maka masyarakat terutama kaum perempuan dan keluarga miskin/pra sejahtera harus diberikan prioritas sebagai target sasaran setiap program pembangunan.
2) Integrasi program-program pembangunan dari pemerintah pusat/provinsi/kabupaten dengan program-program desa dilakukan dengan melihat kondisi objektif kebutuhan masyarakat desa

3) Mengutamakan kegiatan-kegiatan yang bersifat padat karya dengan melibatkan masyarakat desa dalam setiap program pembangunan.

\section{PUSTAKA}

Appel, K., Buckingham, E., Jodoin, K., Roth, D. (2012). Participatory Learning and Action Toolkit: For Application in BSR's Global Programs. Paris: BSR.

Dwipayana A dan Eko S, 2003, Membangun Good Governance di Desa. Yogyakarta, IRE Press

Hasbullah, J. 2006. Social Capital. United Press, Jakarta

Mardikanto T dan Soebiato P, 2013, Pemberdayaan Masyarakat dalam Perspektif Kebijakan Publik. Alfabeta, Bandung.

Mulyadi, D., 2015, Studi Kebijakan Publik dan Pelayanan Publik. Bandung, Alfabeta.

Sutrisno, L. 1995. Menuju Masyarakat Partisipatif. Yogyakarta, Kanisius.

Theresia, Aprillia, at al, 214, Pembangunan Berbasis Masyarakat. Bandung, Alfabeta

Undang-undang Nomor 6 Tahun 2014 tentang Desa 